\title{
Erratum to: DNA hypermethylation and clinicopathological features in breast cancer: the Western New York Exposures and Breast Cancer (WEB) Study
}

\author{
Meng Hua Tao $\cdot$ Peter G. Shields $\cdot$ Jing Nie $\cdot$ Amy Millen $\cdot$ Christine B. Ambrosone $\cdot$ \\ Stephen B. Edge $\cdot$ Shiva S. Krishnan - Catalin Marian · Bin Xie · Janet Winston • \\ Dominica Vito · Maurizio Trevisan · Jo L. Freudenheim
}

Published online: 11 August 2013

(C) Springer Science+Business Media New York 2013

Erratum to: Breast Cancer Res Treat (2009) 114(3):559-568

DOI 10.1007/s10549-008-0028-z

Unfortunately, in the original publication of the article, the grant number in the funding information has been published incorrectly. The correct funding information should be "This work was funded by United States Public Health Service (USPHS) Grant Number R01CA092040 from the National Cancer Institute, and \#DAMD 17030446 and \#DAMD 179616202 from the DOD".

The online version of the original article can be found under doi:10.1007/s10549-008-0028-z.

M. H. Tao $(\bowtie) \cdot$ J. Nie · A. Millen · D. Vito · M. Trevisan .

J. L. Freudenheim

Department of Social and Preventive Medicine, School of Public

Health and Health Professions, University at Buffalo, 270 Farber

Hall, Buffalo, NY 14214, USA

e-mail: mtao@buffalo.edu

P. G. Shields $(\bowtie) \cdot$ S. S. Krishnan · C. Marian · B. Xie

Lombardi Cancer Center, Georgetown University Medical

Center, 3800 Reservoir RD. NW, LL (s) Level, Room 150, Box

571465, Washington, DC 20057, USA

e-mail: pgs2@georgetown.edu

C. B. Ambrosone - S. B. Edge

Department of Cancer Prevention and Control, Roswell Park

Cancer Institute, Buffalo, NY 14263, USA

J. Winston

Potomac Hospital, Woodbridge, VA 22191, USA 